\title{
Sequence Complexities of the Nuclear and Mitochondrial Genomes of the Take-all Fungus, Gaeumannomyces graminis var. tritici
}

\author{
By J. J. P. MCFADDEN AND K. W. BUCK* \\ Department of Pure and Applied Biology, Imperial College of Science and Technology, \\ London $S W 72 B B, U . K$.
}

(Received 13 June 1983)

The nuclear (n) and mitochondrial (mt) genomes of the take-all fungus, Gaeumannomyces graminis var. tritici, were examined by reassociation kinetics with Escherichia coli DNA as internal standard. Only one kinetic component was detected in each DNA, with second-order rate constants of $0.022 \mathrm{M}^{-1} \mathrm{~s}^{-1}$ for nDNA and $10.9 \mathrm{M}^{-1} \mathrm{~s}^{-1}$ for mtDNA, corresponding to sequence complexities of $29 \times 10^{6}$ base pairs and $60 \times 10^{3}$ base pairs respectively.

\section{INTRODUCTION}

Gaeumannomyces graminis var. tritici (hereafter called G. graminis), which causes take-all, an important root-rot disease of wheat and barley, is a homothallic ascomycete fungus (Asher \& Shipton, 1981). Although $G$. graminis has been much studied as a plant pathogen there have been few investigations on the genetics or molecular biology of the fungus. In the present communication we report measurements of the sequence complexities of the nuclear $(n)$ and mitochondrial (mt) genomes of $G$. graminis by DNA reassociation kinetics and compare them with those of other ascomycete fungi.

\section{METHODS}

DNA extraction and characterization. Gaeumannomyces graminis clone $3 \mathrm{bla}$ conE/Al was grown in shaken liquid culture to stationary phase as described previously (McFadden et al., 1983). Isolated nuclei were obtained, and nuclear and total DNA were extracted, by the methods described by Timberlake (1978) for Aspergillus nidulans. Separation of nDNA and mtDNA was achieved by centrifugation in $\mathrm{CsCl}$ density gradients (starting density $1.62 \mathrm{~g} \mathrm{~cm}^{-3}$ ), containing $1 \mathrm{mg}$ ethidium bromide $\mathrm{ml}^{-1}$, at 45000 r.p.m. for $24 \mathrm{~h}$ in a Beckman VTi rotor. Thermal denaturation of DNA was carried out in a Varian Cary 219 spectrophotometer. DNA to be sized was electrophoresed in alkaline agarose gels with $H$ indIII and $E c o$ RI restriction endonuclease digests of phage $\lambda$ DNA and $\varphi$ X174 DNA as standards as described by McDonell et al. (1977).

DNA reassociation kinetics. Denaturation and reassociation of DNA were carried out essentially as described by Britten et al. (1974) except that $10 \mathrm{mM}-\mathrm{Tris} / \mathrm{HCl}, 2 \mathrm{mM}-\mathrm{Na}_{2}$ EDTA, pH 7.6 buffer (for denaturation) and $10 \mathrm{mM}-$ Tris $/ \mathrm{HCl}, 0 \cdot 15 \mathrm{M}-\mathrm{NaCl}, 2 \mathrm{mM}-\mathrm{Na}_{2}$ EDTA, pH 7.6 buffer (for reassociation) were used and the fraction of DNA remaining single-stranded was assayed with S1 nuclease (Hastie et al., 1978). The G. graminis DNA was endlabelled (after sonication) with ${ }^{32} \mathrm{P}$ using $\left[\gamma^{32} \mathrm{P}\right] \mathrm{ATP}$ and polynucleotide kinase (Szekely \& Sanger, 1969), and Escherichia coli DNA, which was used as an internal standard, was labelled with ${ }^{3} \mathrm{H}$, by nick translation (Rigby $e t$ al., 1977). Unlabelled and nick-translated DNA were sonicated to an average size of 500 nucleotides as determined by alkaline agarose gel electrophoresis. It has been shown that when S1 nuclease is used to measure renaturation of randomly sheared DNA, the reaction does not follow ideal second-order kinetics, but follows the form $S / C_{0}=$ $\left\{1 /\left(1+k C_{0} t\right)\right\}^{0 \cdot 45}$, where $S$ is the concentration of totally single-stranded (ss) DNA, $C_{0}$ is the concentration of ssDNA at the start of the reaction, $t$ is time and $k$ is the second-order rate constant (Hastie et al., 1978). This equation rearranges to $1+k C_{0} t=\left(C_{0} / S\right)^{2 \cdot 22}$, so that $k$ can be determined from plots of $\left(C_{0} / S\right)^{2 \cdot 22}$ against $C_{0} t$.

\section{RESULTS AND DISCUSSION}

The total cellular DNA of $G$. graminis had an $A_{260}: A_{280}$ ratio of 2.0 and a hyperchromicity on thermal denaturation of $40 \%$; it migrated in agarose gel electrophoresis with an apparent size of 
$25 \times 10^{3}$ base pairs (bp). After isopycnic centrifugation in caesium chloride density gradients two clear bands near the middle of the gradient were detected. When DNA was prepared from isolated nuclei, only the lower of the two bands was obtained. The lower band therefore represents nDNA and the upper band mtDNA. A similar separation of nDNA and mtDNA in caesium chloride gradients has been reported for another ascomycete fungus, Podospora anserina (Stahl et al., 1978).

The sequence complexities of $G$. graminis nDNA and mtDNA were determined by reassociation kinetics with ${ }^{32} \mathrm{P}$-labelled DNA and ${ }^{3} \mathrm{H}$-labelled $E$. coli DNA as internal standard as described in Methods. Least squares analysis of the data indicated the presence of only one kinetic component for each DNA with second-order rate constants $0.022 \mathrm{M}^{-1} \mathrm{~s}^{-1}$ for $G$. graminis nDNA, $10.9 \mathrm{M}^{-1} \mathrm{~s}^{-1}$ for $G$. graminis mtDNA and $0.14 \mathrm{M}^{-1} \mathrm{~s}^{-1}$ for $E$. coli DNA. Reciprocal $C_{0} t$ plots are shown in Fig. 1. Taking the genome size for $E$. coli to be $4.6 \times 10^{6}$ bp (Zimmerman \& Goldberg, 1977), the sequence complexity of G. graminis nDNA was calculated to be $29 \times 10^{6} \mathrm{bp}$. This value is similar to the nuclear genome sizes of two other ascomycete fungi, Aspergillus nidulans $\left(26 \times 10^{6} \mathrm{bp}\right.$, Timberlake, 1978) and Neurospora crassa $\left(27 \times 10^{6} \mathrm{bp}\right.$, Krumlauf \& Marzluf, 1980). Furthermore, the detection of only one kinetic component indicates the absence of substantial amounts of repetitive DNA. In this respect it is significant that Timberlake (1978) found only 2 to $3 \%$ of reiterated sequences (probably the genes for ribosomal RNA) in the $A$. nidulans nuclear genome and these sequences could only be detected after a hydroxyapatite enrichment procedure. Our results support Timberlake's suggestion that the ascomycete fungi do not contain interspersed reiterated DNA sequences as found in the higher eukaryotes.

The sequence complexity of $G$. graminis mtDNA was calculated to be $60 \times 10^{3} \mathrm{bp}$. This is within the range of mitochondrial genome sizes found for other ascomycetes (cf. A. nidulans, 32 $\times 10^{3} \mathrm{bp}$, Grisi et al., 1982; N. crassa, $62 \times 10^{3} \mathrm{bp}$, Bernard et al., 1975; Saccharomyces cerevisiae, $70 \times 10^{3} \mathrm{bp}$, Caron et al., 1979; P. anserina, $95 \times 10^{3} \mathrm{bp}$, Cummings et al., 1979). Since mtDNA comprised $20 \%$ of the total DNA in G. graminis grown to stationary phase and since the fungus is haploid and hyphal compartments are predominantly uninucleate (Asher \& Shipton, 1981), it can be calculated that there are about 100 copies of mtDNA per hyphal compartment. This compares with 100 copies of mtDNA found in stationary phase cells of $S$. cerevisiae (Caron et al., 1979).

Many isolates of G. graminis are infected with double-stranded (ds) RNA virus particles (Buck et al., 1981). Knowledge of the sizes of the $\mathrm{n}$ and $\mathrm{mt}$ genomes reported here, together with determination of the cellular dsRNA/DNA ratio, has recently enabled us to determine the average number of dsRNA molecules (and hence virus particles) per hyphal compartment (300

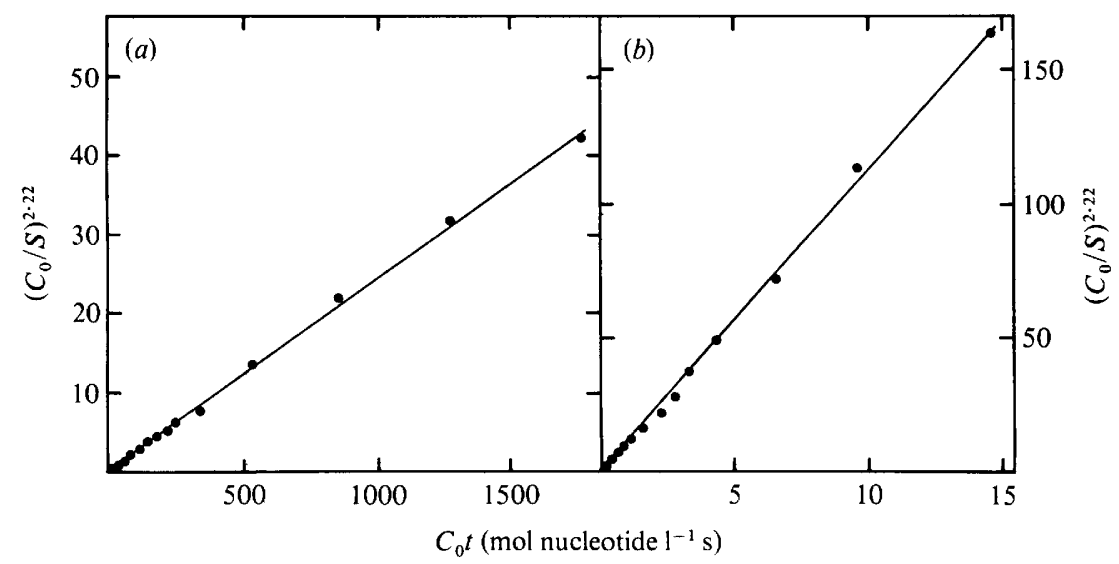

Fig. 1. Reciprocal $C_{0} t$ plots of (a) nDNA and (b) mtDNA from G. graminis. See Methods for terminology. 
for G. graminis isolate 3bla; McFadden et al., 1983). This value compares with 200 to 1000 molecules of $\mathrm{L}$ dsRNA per cell found in most isolates of $S$. cerevisiae (Brewer \& Fangman, 1980).

We thank Dr C. J. Rawlinson for providing G. graminis isolates and for useful discussions, Dr P. W. J. Rigby for advice and the Science and Engineering Research Council for the award of a studentship (to J.J.P.M.)

\section{REFERENCES}

ASher, M. J. C. \& SHIPTON, P. J. (1981). Biology and Control of Take-all. London \& New York: Academic Press.

Bernard, U.. Bade, E. \& KüNTZEL, H. (1975). Specific fragmentation of mitochondrial DNA from Neurospora crassa by restriction endonuclease EcoRI. Biochemical and Biophysical Research Communications 64, 783-789.

Brewer, B. J. \& Fangman, W. L. (1980). Preferential inclusion of extrachromosomal genetic elements in yeast meiotic spores. Proceedings of the National Academy of Sciences of the United States of America 77, 5380-5384.

Britten, R. J., Graham, D. E. \& Neufeld, B. R. (1974). Analysis of repeating DNA sequences by reassociation. Methods in Enzymology 29, 363-418.

Buck, K. W., Almond, M. R., McFadden, J. J. P., Romanos, M. A. \& Rawlinson, C. J. (1981). Properties of thirteen viruses and virus variants obtained from eight isolates of the wheat take-all fungus Gaeumannomyces graminis var. tritici. Journal of General Virology 53, 235-245.

Caron, F., JacQ, C. \& Rouviere-Yaniv, J. (1979). Characterisation of a histone-like protein extracted from yeast mitochondria. Proceedings of the National Academy of Sciences of the United States of America 76, 4265-4269.

Cummings, D. J., Belcour, L. \& Grandchamp, C. (1979). Mitochondrial DNA from Podospora anserina. I. Isolation and characterisation. Molecular and General Genetics 171, 229-238.

Grisi, E., Brown, T. A., Waring, R. B., ScazzocCHIo, C. \& DAvies, R. W. (1982). Nucleotide sequence of a region of the mitochondrial genome of Aspergillus nidulans including the gene for ATPase subunit 6. Nucleic Acids Research 10, 3531-3539.

Hastie, N. D., Brennan, V. \& Bruenn, J. A. (1978).
No homology between double-stranded RNA and nuclear DNA of yeast. Journal of Virology 28, 10021005.

Krumlauf, R. \& Marzluf, G. A. (1980). Genome organisation and characterisation of the repetitive and inverted repeat DNA sequences in Neurospora crassa. Journal of Biological Chemistry 255, 11381145.

McDonell, M. W., Simon, M. N. \& Studier, F. W. (1977). Analysis of restriction fragments of T7 DNA and determination of molecular weights by electrophoresis in neutral and alkaline gels. Journal of Molecular Biology 110, 119-146.

MCFADDEN, J. J. P., BuCK, K. W. \& Rawlinson, C. J. (1983). Infrequent transmission of double-stranded RNA particles but absence of DNA proviruses in single ascospore cultures of Gaeumannomyces graminis. Journal of General Virology 64, 927-937.

Rigby, P. W. J., DieckmanN, M., RHodes, C. \& Berg, P. (1977). Labelling of deoxyribonucleic acid to high specific activity in vitro by nick translation with DNA polymerase 1. Journal of Molecular Biology 113, 237-251.

Stahl, U., Lemke, P. A., TudzynSKI, P., KücK, U. \& EsSER, K. (1978). Evidence for plasmid-like DNA in a filamentous fungus, the ascomycete Podospora anserina. Molecular and General Genetics 162, 341343.

Szekely, M. \& SANGer, F. (1969). Use of polynucleotide kinase in fingerprinting non-radioactive nucleic acids. Journal of Molecular Biology 43, 607-617.

Timberlake, W. E. (1978). Low repetitive DNA content in Aspergillus nidulans. Science 202, 973975.

Zimmerman, J. L. \& GoldberG, R. B. (1977). DNA sequence organisation in the genome of Nicotiana tabacum. Chromosoma 59, 227-252. 